\title{
Bone Pyrophosphate in Uremia and Its Association with Extraosseous Calcification
}

\author{
Allen C. Alfrey and Clive C. Solomons with the technical assistance \\ of J. CirCllLo and N. MiLler \\ From the Renal Section, Denver Veterans Administration Hospital, the \\ Division of Renal Medicine, and Department of Pediatrics, University of \\ Colorado Medical Center, Denver, Colorado 80220
}

A в S T R A C T The mean bone pyrophosphate was 0.360 $\pm 0.15 \mathrm{mg} / \mathrm{g}$ in 8 controls and $1.22 \pm 1.39 \mathrm{mg} / \mathrm{g}$ bone in 27 uremic patients $(P<0.0025) .13$ of the 27 uremic patients had bone pyrophosphate levels greater than $2 \mathrm{SD}$ above control values.

The ash content of uremic bones with increased pyrophosphate levels (group II) was $56 \pm 9 \%$ as compared to $64 \pm 2 \%$ in control bones $(P<0.01)$ and $60 \pm 7 \%$ in uremic bones having normal pyrophosphate levels $(P<$ 0.1 ) (group I). The magnesium content of bones in group II was $338 \pm 47$ as compared to $211 \pm 13$ ( $P<$ $0.0005)$ in the controls and $294 \pm 73 \mathrm{mmol} / \mathrm{kg}$ ash $(P<$ 0.05 ) in group I. In group II, but not group I, there was a significant inverse correlation between duration of dialysis and percent bone ash $(r=-0.59)(P<0.05)$.

A definite relationship existed between elevated bone pyrophosphate levels and soft tissue calcification. In group II the mean pulmonary calcium content was $530 \pm$ 459 as compared to $32 \pm 26 \mathrm{mmol} / \mathrm{kg} / \mathrm{ash}$ in group I $(P<$ $0.0025)$. All patients with a bone pyrophosphate level greater than $1.4 \mathrm{mg} / \mathrm{g}$ bone had extensive pulmonary calcification.

It is concluded that the excess bone pyrophosphate present in some uremic patients is either deposited in the apatite crystal in the transphosphorylated form or else as the magnesium salt since the pyrophosphate is resistant to pyrophosphatase and surface adsorption of pyrophosphate is not altered by the increased bone pyrophosphate levels. The excess bone pyrophosphate could disturb bone calcification mechanisms in uremic patients. The association between increased bone pyrophosphate and soft tissue calcification suggests that the disordered pyrophosphate metabolism may be important in the pathogenesis of extraosseous calcification.

Received for publication 8 August 1975 and in revised form 29 October 1975.

\section{INTRODUCTION}

There are a number of reasons to think that a crystal inhibitor or stabilizer such as pyrophosphate $\left(\mathrm{P}_{2} \mathrm{O}_{2}\right)^{1}$ may be important in altering the calcification mechanisms in uremic patients. Since the urine normally contains a number of substances including $\mathrm{P}_{2} \mathrm{O}_{7}$ which inhibit the precipitation of calcium and phosphate from solution (1), it is expected that some of these compounds are retained by patients with severely compromised renal function. Somewhat in support of this view is the study of Yendt et al. (2) which showed that substances present in the sera of uremic patients inhibited the in vitro calcification of rachitic rat cartilage. More direct evidence that $\mathrm{P}_{2} \mathrm{O}_{7}$ metabolism is altered in dialyzed uremic patients is the finding of high $\mathrm{P}_{2} \mathrm{O}_{7}$ levels in visceral calcium-phosphate deposits in these patients (3). In addition, elevated plasma and serum $\mathrm{P}_{2} \mathrm{O}_{7}$ levels have been reported in some uremic patients by Russell et al. (4) and David et al. (5). Although the local concentration of inhibitors could be important in preventing the transformation of amorphous calcium phosphate to apatite $\left[\mathrm{CA}_{10}\left(\mathrm{PO}_{4}\right)_{8} \cdot(\mathrm{OH})_{2}\right]$, bone $\mathrm{P}_{2} \mathrm{O}_{7}$ levels have not previously been measured in uremic patients.

The present study was carried out to measure bone $\mathrm{P}_{2} \mathrm{O}_{7}$ levels in uremic patients, to correlate bone $\mathrm{P}_{2} \mathrm{O}_{7}$ content with other inorganic constituents of bone, and to determine if any relationship exists between bone $\mathrm{P}_{2} \mathrm{O}_{7}$ levels and soft tissue calcification.

\section{METHODS}

Bone was obtained from 27 uremic patients, 8 control subjects, and 3 patients with osteomalacia not associated with uremia. Two of the latter patients had vitamin D deficiency and one had Fanconi's syndrome. The bone was uniformily

${ }^{1}$ Abbreviation used in this paper: $\mathrm{P}_{2} \mathrm{O}_{7}$, pyrophosphate. 
TABLE I

Effect of Inorganic Pyrophosphatase on Bone $\mathrm{P}_{2} \mathrm{O}_{7}$

\begin{tabular}{|c|c|c|}
\hline & \multicolumn{2}{|c|}{$\mathrm{P}_{2} \mathrm{O}_{7}(\mathrm{P})$} \\
\hline & Control & $\begin{array}{c}\text { After } 2 \mathrm{~h} \\
\text { incubation } \\
\text { with Pase* }\end{array}$ \\
\hline & \multicolumn{2}{|c|}{$m g / g$ dry bone } \\
\hline \multicolumn{3}{|l|}{ Uremic bones } \\
\hline 1 & 1.72 & 1.55 \\
\hline 2 & 0.68 & 0.67 \\
\hline 3 & 0.78 & 0.72 \\
\hline \multicolumn{3}{|l|}{ Control bones } \\
\hline 1 & 0.38 & 0.37 \\
\hline 2 & 0.30 & 0.37 \\
\hline 3 & 0.25 & 0.29 \\
\hline \multicolumn{3}{|l|}{ Synthetic apatite } \\
\hline Preequilibrated (1) & 1.63 & 1.01 \\
\hline With $\mathrm{P}_{2} \mathrm{O}_{7}$ & 1.87 & 1.04 \\
\hline $\mathrm{Na}_{4} \mathrm{P}_{2} \mathrm{O}_{7}$ & 0.61 & $0.02 \mathrm{mg} \ddagger$ \\
\hline
\end{tabular}

* Pase, inorganic pyrophosphatase.

$\ddagger 10$-min incubation period.

obtained from the iliac crest either at time of autopsy or by biopsy. The bone was kept in a frozen state until time of analysis. The adhering periosteous and tissue was removed from the bone by scraping with a scalpel. Cortical and trabecular bone were separated and the marrow removed by washing with a jet of deionized water. The trabecular bone was dried at room temperature. The bone sample was then ground in a Wiley mill and passed through a 20 -mesh sieve. Partial defatting was accomplished by rinsing four times with petroleum ether (bp $30-60^{\circ} \mathrm{C}$ ). The bone was reground and passed through a 60 -mesh sieve. $25 \mathrm{mg}$ of the ground bone was placed in $2 \mathrm{ml}$ of saturated solution of EDTA with the $\mathrm{pH}$ adjusted to 7.4. $\mathrm{Ca}, \mathrm{Mg}, \mathrm{P}$, and $\mathrm{P}_{2} \mathrm{O}_{7}$ determinations on bone and soft tissues were carried out by previously described techniques $(3,6)$. The completeness of the EDTA extraction was verified by ashing the residue and determining $\mathrm{Ca}, \mathrm{Mg}$, and $\mathrm{P}$ content. Percent bone ash was determined by weighing the bone sample after drying at $130^{\circ} \mathrm{C}$ for 16 $\mathrm{h}$ and again after incineration at $450^{\circ} \mathrm{C}$ for $16 \mathrm{~h}$. ([Ash wt/ dry wt $] \times 100=\%$ ash .

For bone density determinations, unground trabecular bone was suspended from a fine wire and weighed both in air and after emersion in deionized water after the removal of all trapped air. Volume equals the difference in weight per unit weight of water at ambient temperature. Density equals air-stable weight per unit volume. Density $=$ wt air $/$ wt air - wt water.

Inorganic pyrophosphatase with a specific activity of 647 $\mathrm{U} / \mathrm{mg}$ protein was obtained from Sigma Chemical Co., St. Louis, Mo., and had a reported activity of $1 \mathrm{U}$ capable of liberating $1.0 \mu \mathrm{mol}$ of inorganic othophosphate per $\mathrm{min}$ at $\mathrm{pH}$ 7.2 at $25^{\circ} \mathrm{C}$. In all studies, $3 \mathrm{U}$ of pyrophosphatase was used in a solution containing Tris buffer ( $\mathrm{pH} 7.2) 25 \mathrm{mM} \mathrm{NaCl}$, and $1 \mathrm{mM} \mathrm{MgCl}$. Activity of the enzyme was verified by using a $\mathrm{Na}_{4} \mathrm{P}_{2} \mathrm{O}_{7}$ standard.

To determine if storage of frozen bone affected the $\mathrm{P}_{2} \mathrm{O}_{7}$ content, six bones were analyzed before and after $6 \mathrm{mo}$ of freezing. The mean $\mathrm{P}_{3} \mathrm{O}_{7}$ content in the six bones before freezing was 0.59 and after freezing $0.67 \mathrm{mg} / \mathrm{g}$ bone $(P>0.20)$. To exclude the possibility that hydrolysis of $\mathrm{P}_{2} \mathrm{O}_{7}$ occurred during the EDTA extraction, $\mathrm{P}_{2} \mathrm{O}_{7}$ measurements were performed on paired samples extracted for 2 and $24 \mathrm{~h}$ at $4^{\circ} \mathrm{C}$ and room temperature. $\mathrm{P}_{2} \mathrm{O}_{7}$ measurements were similar in all samples. All $\mathrm{P}_{2} \mathrm{O}_{7}$ results are expressed as milligrams of $\mathrm{P}_{2} \mathrm{O}_{7} \mathrm{P}$.

Statistical comparisons were carried using the $t$ test. All results are given as mean $\pm 1 \mathrm{SD}$.

\section{RESULTS}

Bone pyrophosphate. The mean bone content in 8 control bones was $0.360 \pm 0.150$ and in 27 uremic bones was $1.22 \pm 1.39 \mathrm{mg} / \mathrm{g}$ dry bone $(P<0.0025)$. The bone $\mathrm{P}_{2} \mathrm{O}_{7}$ levels in 13 of the 27 uremic patients were greater than $2 \mathrm{SD}$ above control values.

To determine if the bone $\mathrm{P}_{2} \mathrm{O}_{7}$ was resistant to the action of inorganic pyrophosphatase, $25 \mathrm{mg}$ of finely ground bone powder from controls and uremic patients was incubated with $3 \mathrm{U}$ of inorganic pyrophosphatase for 2 $h$ in a solution containing Tris buffer ( $\mathrm{pH} 7.2)$ and magnesium. Synthetic apatite crystals (verified by X-ray diffraction analysis to have a crystal size similar to bone) previously equilibrated with $\mathrm{P}_{2} \mathrm{O}_{7}$, so that its $\mathrm{P}_{2} \mathrm{O}_{7}$ content was similar to that found in bone, was also incubated in the pyrophosphatase solution. Although the pyrophosphatase destroyed over $94 \%$ of sodium $\mathrm{P}_{2} \mathrm{O}_{7}$ and decreased the $\mathrm{P}_{2} \mathrm{O}_{7}$ adsorbed on synthetic apatite by over $40 \%$ it produced no consistent change in the $\mathrm{P}_{2} \mathrm{O}_{7}$ content of uremic and control bones (Table I).

25-mg samples of control and uremic bones containing normal and elevated $\mathrm{P}_{2} \mathrm{O}_{7}$ levels were incubated in $2 \mathrm{ml}$ of a solution containing $36 \mu \mathrm{g} / \mathrm{ml}$ (P) $\mathrm{P}_{2} \mathrm{O}_{7}$ for $1 \mathrm{~h}$ to measure $\mathrm{P}_{2} \mathrm{O}_{7}$ adsorption by the bone crystals. The results expressed on an ash weight basis are shown in Table II. $\mathrm{P}_{2} \mathrm{O}_{7}$ uptake was similar in all bones irrespective of the initial $\mathrm{P}_{2} \mathrm{O}_{7}$ content. Synthetic apatite crystals took up slightly less $\mathrm{P}_{2} \mathrm{O}_{7}$ than the bone crystals (Table II).

To exclude the possibility that an increased amount of noncalcified bone matrix was responsible for the high $\mathrm{P}_{2} \mathrm{O}_{7}$ levels found in some uremic bones, $\mathrm{P}_{2} \mathrm{O}_{7}$ was mea-

TABLE II

$\mathrm{P}_{2} \mathrm{O}_{7}$ Equilibration Study

\begin{tabular}{lccc}
\hline & $\begin{array}{c}\text { Pre- } \\
\text { incubation }\end{array}$ & $\begin{array}{c}\text { Post- } \\
\text { incubation }\end{array}$ & $\begin{array}{c}\text { Amount } \\
\text { adsorbed }\end{array}$ \\
\hline Uremic bone & \multicolumn{4}{c}{$\mu g(P) P_{2} O_{7} / m g$ bone ash } \\
Uremic bone & 4.26 & 6.29 & 2.03 \\
Control bone & 0.48 & 2.48 & 2.00 \\
Synthetic apatite & 0.49 & 2.57 & 2.08 \\
& 0 & 1.63 & 1.63 \\
\hline
\end{tabular}

The incubating media contained $36 \mu \mathrm{g} / \mathrm{ml}(\mathrm{P}) \mathrm{Na}_{4} \mathrm{P}_{2} \mathrm{O}_{7}$. 


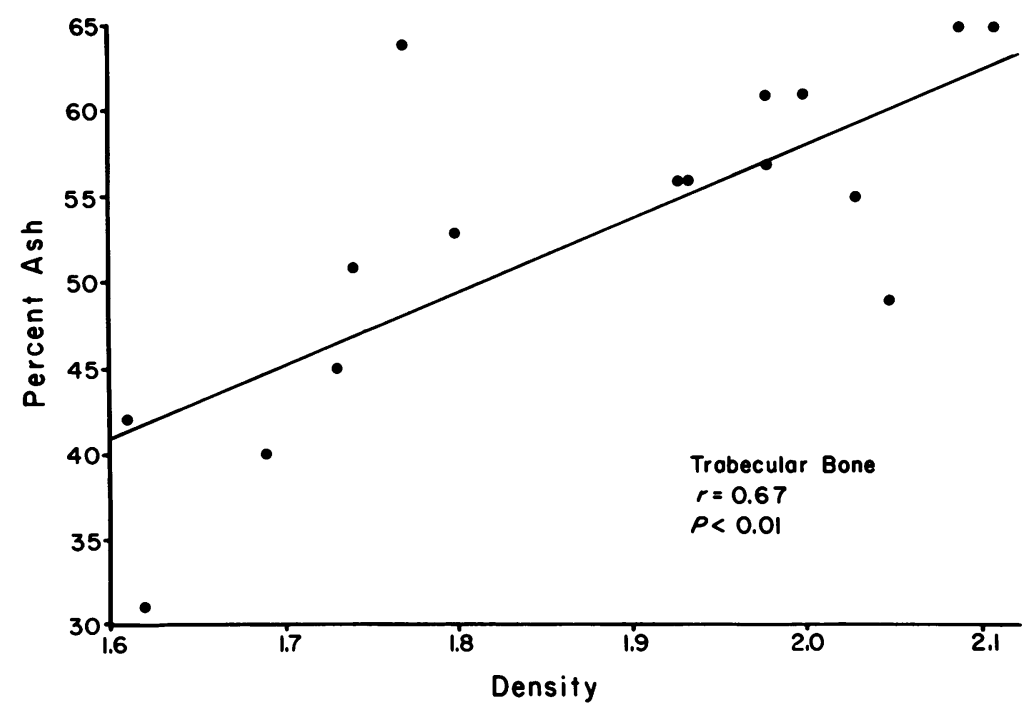

FIGURE 1 Correlation between bone density and percent ash. Bones were obtained from controls, and uremic patients with normal, osteomalacic, and fibrotic bone disease.

sured in bones obtained from three patients who had osteomalacia of nonuremic causes (Table III). In all of these patients bone $\mathrm{P}_{2} \mathrm{O}_{7}$ was within the normal range.

Additional inorganic constituents of bone. Bones from the uremic patients were subdivided into two groups. Group I had bone $\mathrm{P}_{2} \mathrm{O}_{7}$ levels within the normal range and group II had bone $\mathrm{P}_{2} \mathrm{O}_{7}$ levels greater than $2 \mathrm{SD}$ above normal (Table IV). In both uremic groups, the bone calcium was significantly lower $(P<0.025)$ and magnesium significantly higher $(P<0.0025)$ than the controls. Group I patients had a slightly lower bone phosphorus than the controls and group II patients had significantly lower bone ash content than the controls $(P<0.01)$. In comparing the two uremic groups group II patients had significantly higher bone magnesium content $(P<0.05)$ and somewhat lower bone ash content than group I patients. Bone phosphorus was also slightly higher in group II patients (Table IV).

Bone density was measured in 16 bones and found to correlate with bone ash content $(r=0.67) \quad(P<0.01)$ (Fig. 1). Low percent ash, and in turn, reduced bone density was found in osteomalacic as well as fibrotic bones and could not be used to separate the type of bone

TABLE III

$\mathrm{P}_{2} \mathrm{O}_{7}$ in Bones of Patients with Other Types of Osteomalacia

\begin{tabular}{lcc}
\hline & Ash & $\mathrm{P}_{8} \mathrm{O}_{7}(\mathrm{P})$ \\
\hline & $\%$ & $m g / g$ bone \\
Vitamin D deficiency & 41 & 0.200 \\
Vitamin D deficiency & 56 & 0.436 \\
Fanconi syndrome & 31 & 0.630 \\
\hline
\end{tabular}

disease. Since it was easier and more reproducible to measure bone ash than density the former determination was used for comparative purposes in this study. In the high bone $\mathrm{P}_{2} \mathrm{O}_{7}$ group (group II) there was a significant negative correlation between duration of dialysis and percent bone ash $(r=-0.59)(P<0.05)$ (Fig. 2). Such a correlation was not found in group I $(r=-$ 0.43) $(P<0.1)$. No correlation was found between duration of dialysis and bone $\mathrm{P}_{3} \mathrm{O}_{7}$ content $(r=0.16)$ $(P<0.1)$ (Fig. 3).

Correlation between bone $\mathrm{P}_{\mathrm{B}} \mathrm{O}_{7}$ and soft tissue calcification. Heart and/or lung calcium content was measured in 8 control subjects, 10 patients in group I and II patients in group II. The cardiac and pulmonary calcium content was significantly higher in uremic patients having high bone $\mathrm{P}_{2} \mathrm{O}_{7}$ levels (group II) when compared to controls $(P<0.0025)$ and group I $(P<0.0025)$. In all patients with bone $\mathrm{P}_{2} \mathrm{O}_{7}$ above $1.4 \mathrm{mg} / \mathrm{g}$ there was extensive pulmonary calcification (Table $\mathrm{V}$ ).

In association with the pulmonary calcium-phosphate deposits the $\mathrm{P}_{2} \mathrm{O}_{7}$ content of the lung was also increased whereas in uremic patients without pulmonary calcification lung $\mathrm{P}_{2} \mathrm{O}_{7}$ was within the normal range (Table VI). The only nondialyzed uremic patient studied who had pulmonary calcification (Table VI) had low bone and pulmonary $\mathrm{P}_{2} \mathrm{O}_{7}$ levels. This deposit had the thermochemical properties of hypercalcemic visceral calcification (3).

\section{DISCUSSION}

Bone $\mathrm{P}_{2} \mathrm{O}_{7}$ content was found to be significantly higher in dialyzed uremic patients as compared to control subjects. In control bones approximately $0.35 \%$ of the phos- 
TABLE IV

Inorganic Constituents of Bone

\begin{tabular}{|c|c|c|c|c|c|}
\hline & $\mathrm{Ca}$ & $\mathbf{M g}$ & $\mathbf{P}$ & $\mathrm{P}_{2} \mathrm{O}_{7}(\mathrm{P})$ & Ash \\
\hline & \multicolumn{3}{|c|}{$\mathrm{mmol} / \mathrm{kg}$ ash } & $m g / g$ dry bone & $\%$ \\
\hline \multicolumn{6}{|c|}{ Normals } \\
\hline 1 & 9,125 & 206 & 5,511 & 0.339 & 62 \\
\hline 2 & 9,500 & 206 & 5,650 & 0.330 & 63 \\
\hline 3 & 9,274 & 207 & 5,295 & 0.320 & 64 \\
\hline 4 & 9,636 & 236 & 5,750 & 0.530 & 63 \\
\hline 5 & 9,481 & 214 & 5,636 & 0.480 & 63 \\
\hline 6 & 9.574 & 199 & 5,613 & 0.376 & 67 \\
\hline Mean & 9,432 & 211 & 5,576 & 0.396 & 64 \\
\hline SD & 194 & 13 & 157 & 0.088 & 2 \\
\hline \multicolumn{6}{|c|}{ Group 1, Uremic } \\
\hline 1 & 9,230 & 278 & 5,451 & 0.140 & 67 \\
\hline 2 & 9,040 & 426 & 5,484 & 0.330 & 40 \\
\hline 3 & 9,090 & 212 & 5,323 & 0.300 & 65 \\
\hline 4 & 9,447 & 322 & 5,548 & 0.310 & 60 \\
\hline 5 & 8,781 & 279 & 5,623 & 0.290 & 65 \\
\hline 6 & 9,468 & 248 & 5,456 & 0.560 & 59 \\
\hline 7 & 9,000 & 288 & - & 0.640 & 65 \\
\hline 8 & 9,248 & 243 & 5,448 & 0.589 & 64 \\
\hline 9 & 9,125 & 368 & - & 0.510 & 57 \\
\hline 10 & 9,196 & 210 & - & 0.396 & 66 \\
\hline 11 & $\mathbf{9 , 4 3 7}$ & 412 & - & 0.536 & 60 \\
\hline 12 & 8,890 & 247 & - & 0.350 & 55 \\
\hline Mean & 9,163 & 294 & 5,476 & 0.413 & 60 \\
\hline SD & 220 & 73 & 93 & 0.152 & 7 \\
\hline \multicolumn{6}{|c|}{ Group II, Uremic } \\
\hline 1 & 8,968 & 373 & - & 3.60 & 54 \\
\hline 2 & 8,856 & 330 & 5,387 & 2.73 & 64 \\
\hline 3 & 9,316 & 369 & 5,765 & 2.47 & 49 \\
\hline 4 & 9,250 & 312 & 5,800 & 2.17 & 66 \\
\hline 5 & 8,337 & 326 & - & 1.78 & 48 \\
\hline 6 & 9,012 & 270 & 5,452 & 1.41 & 66 \\
\hline 7 & 8.914 & 434 & 5,670 & 1.22 & 51 \\
\hline 8 & 9,624 & 356 & 5,419 & 1.06 & 57 \\
\hline 9 & 9,125 & 363 & - & 1.64 & 38 \\
\hline 10 & 9,000 & 312 & - & 0.72 & 53 \\
\hline 11 & 9,848 & 277 & 5,645 & 0.86 & 65 \\
\hline Mean & 9,114 & 338 & 5,591 & 1.787 & 56 \\
\hline SD & 402 & 47 & 170 & 0.883 & 9 \\
\hline
\end{tabular}

$P$ values: Normal vs. group II, $<0.05,<0.0005,<0.45,<0.0005,<0.01$; normal vs. group I, $<0.01,<0.0025,<0.1,<0.4,<0.1$; group II vs. group I, $<0.4,<0.05,<0.1,<0.0005,<0.1$.

phorus and in uremic bone $1.2 \%$ of the phosphorus was present as $\mathrm{P}_{2} \mathrm{O}_{7}$. Only a limited number of other studies have been carried out to measure $\mathrm{P}_{2} \mathrm{O}_{7}$ content of calcified tissues. Perkins and Walker (7) found that between 0.25 and $0.73 \%$ of the phosphorus present in rabbit and rat cortical bone, and Cartier (8) found that 0.68 to $0.79 \%$ of the phosphorus present in rat bone was $\mathrm{P}_{2} \mathrm{O}_{7}$. Bisaz et al. (9) reported that 0.69 and $0.13 \%$ of the phosphorus in dentin and enamel, respectively, was $\mathrm{P}_{2} \mathrm{O}_{7}$. Thus the $\mathrm{P}_{2} \mathrm{O}_{7}$ content of control human bones in our study is quite similar to that found by other authors in a variety of calcified tissues; but the $\mathrm{P}_{2} \mathrm{O}_{7}$ content of uremic bone is considerably higher.

Burton et al. (10) found that $\mathrm{P}_{2} \mathrm{O}_{7}$ was rapidly adsorbed from an incubating media onto the surface of apatite crystals. These authors suggested that a fixed num- ber of binding sites were available for $\mathrm{P}_{2} \mathrm{O}_{7}$ adsorption by the crystal surface. The studies of Krane and Glimcher (11) and Jung et al. (12) show that $\mathrm{P}_{2} \mathrm{O}_{7}$ binding by apatite crystals is not restricted to one class of binding sites. Krane and Glimcher (11) found that apatite crystals when incubated with inorganic pyrophosphate took up $\mathrm{P}_{2} \mathrm{O}_{7}$ rapidly as a result of adsorption on the crystal surface. The $\mathrm{P}_{2} \mathrm{O}_{7}$ adsorbed by the apatite crystal could be hydrolyzed by pyrophosphatase. A second type of binding occurred when the crystals were exposed to ATP. It was suggested that there was a phosphoryl transfer of the terminal phosphoryl of the nucleotide to form $\mathrm{P}_{2} \mathrm{O}_{7}$ $(11,13)$. The $\mathrm{P}_{2} \mathrm{O}_{7}$ formed by this reaction appears to be bound to the crystal as a result of a transphosphorylation reaction between the $\mathrm{P}_{2} \mathrm{O}_{7}$ and phosphorus of the apatite crystal $(11,13)$. The $\mathrm{P}_{2} \mathrm{O}_{7}$ present in apatite crystals in this form is resistant to pyrophosphatase (11).

TABLE V

Soft Tissue Calcification

\begin{tabular}{|c|c|c|c|}
\hline & $\begin{array}{c}\text { Bone } \\
\mathrm{P}_{2} \mathrm{O}_{7}(\mathrm{P})\end{array}$ & $\begin{array}{l}\text { Lung } \\
\text { Ca }\end{array}$ & $\begin{array}{c}\text { Heart } \\
\mathrm{Ca}\end{array}$ \\
\hline & $m g / g d r y$ bone & & issue \\
\hline \multicolumn{4}{|c|}{ Group I } \\
\hline 1 & 0.51 & 25 & 12 \\
\hline 2 & 0.31 & 25 & 9 \\
\hline 3 & 0.33 & 48 & 8 \\
\hline 4 & 0.30 & 13 & 5 \\
\hline 5 & 0.14 & 13 & 5 \\
\hline 6 & 0.56 & 100 & 13 \\
\hline 7 & 0.61 & 16 & 16 \\
\hline 8 & 0.40 & 32 & 13 \\
\hline 9 & 0.54 & 25 & 44 \\
\hline 10 & 0.35 & 25 & 25 \\
\hline Mean & 0.41 & 32 & 15 \\
\hline $\mathrm{SD}$ & 0.15 & 26 & 12 \\
\hline \multicolumn{4}{|c|}{ Group II } \\
\hline 1 & 6.56 & 627 & 32 \\
\hline 2 & 3.60 & 625 & 424 \\
\hline 3 & 2.73 & 1,164 & 40 \\
\hline 4 & 2.42 & 375 & 375 \\
\hline 5 & 2.17 & 461 & 15 \\
\hline 6 & 1.78 & 1,475 & 37 \\
\hline 7 & 1.41 & 533 & 575 \\
\hline 8 & 1.22 & 32 & 28 \\
\hline 9 & 1.06 & 21 & - \\
\hline 10 & 0.86 & 496 & 8 \\
\hline 11 & 0.72 & 23 & 13 \\
\hline Mean & 2.23 & 530 & 154 \\
\hline $\mathrm{SD}$ & 1.68 & 459 & 215 \\
\hline \multicolumn{4}{|c|}{ Controls } \\
\hline Mean & 0.36 & 19 & 11 \\
\hline SD & 0.15 & 6 & 5 \\
\hline
\end{tabular}

Bone Pyrophosphate in Uremia 


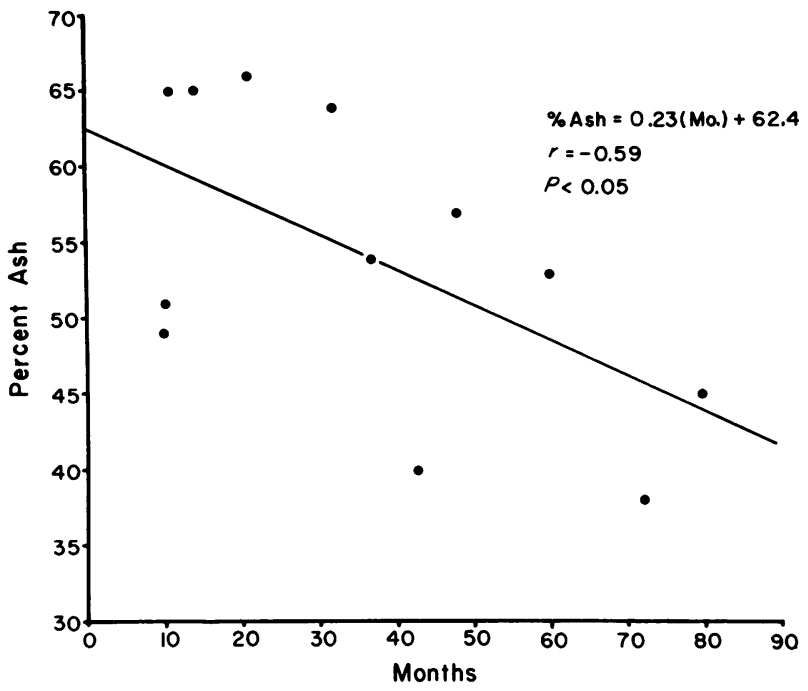

FIgURE 2 Correlation between duration of dialysis and percent bone ash in all uremic patients' bones containing $\mathrm{P}_{2} \mathrm{O}_{7}$ levels greater than $2 \mathrm{SD}$ above control values.

Two pieces of evidence are presented in this study which would suggest that in uremic patients the excess bone $\mathrm{P}_{2} \mathrm{O}_{7}$, if it is attached to the apatite crystal, is formed in situ and present in the transphosphorylated form. First, the amount of $\mathrm{P}_{2} \mathrm{O}_{7}$ adsorbed from an incubating media by control bones and uremic bones with normal and high $\mathrm{P}_{2} \mathrm{O}_{7}$ levels was similar. It would be expected that if the excess $\mathrm{P}_{2} \mathrm{O}_{7}$ had been present as a result of being adsorbed on the crystal surface that additional $\mathrm{P}_{2} \mathrm{O}_{7}$ adsorption would be decreased because of a reduced number of available binding sites. Secondly the $\mathrm{P}_{2} \mathrm{O}_{7}$ present in all types of bone was resistant to hy-

TABLE VI

Bone $\mathrm{P}_{2} \mathrm{O}_{7}$ vs. Soft Tissue $\mathrm{P}_{2} \mathrm{O}_{7}$

\begin{tabular}{|c|c|c|c|}
\hline & \multirow{2}{*}{$\begin{array}{c}\text { Bone } \\
\mathrm{P}_{2} \mathrm{O}_{7}(\mathrm{P})\end{array}$} & \multicolumn{2}{|c|}{ Lung } \\
\hline & & $\mathrm{Ca}$ & $\mathrm{P}_{2} \mathrm{O}_{7}(\mathrm{P})$ \\
\hline \multicolumn{4}{|c|}{$m g / g d r y$ weight } \\
\hline \multicolumn{4}{|l|}{ Patient } \\
\hline $1^{*}$ & 1.78 & 29 & 7.5 \\
\hline $2^{*}$ & 6.56 & 24 & 4.6 \\
\hline $3^{*}$ & 2.42 & 15 & 3.0 \\
\hline $4^{*}$ & 2.17 & 16 & 3.0 \\
\hline $5^{*}$ & 3.60 & 24 & 3.5 \\
\hline 6 & 0.14 & 0.5 & 1.40 \\
\hline 7 & 0.72 & 0.9 & 0.53 \\
\hline 8 & 0.30 & 0.5 & 0.85 \\
\hline $9^{*} \ddagger$ & 0.42 & 10 & 1.45 \\
\hline
\end{tabular}

* Patient with calcification.

$\ddagger$ Nondialyzed uremic.

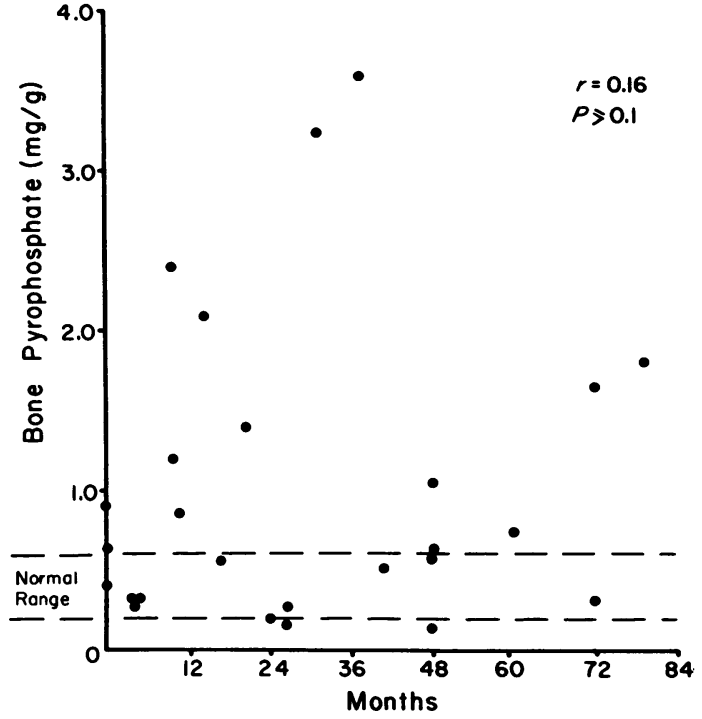

Figure 3 Correlation between bone $\mathrm{P}_{2} \mathrm{O}_{7}$ levels and duration of dialysis in all dialyzed uremic patients.

drolysis by pyrophosphatase. Since bone with high $\mathrm{P}_{2} \mathrm{O}_{7}$ levels also contain large amounts of magnesium a final possibility is that the $\mathrm{P}_{2} \mathrm{O}_{7}$ in bone is deposited as a magnesium salt. This would also explain why surface adsorption of $\mathrm{P}_{2} \mathrm{O}_{7}$ was unchanged and the excess bone $\mathrm{P}_{2} \mathrm{O}_{7}$ was resistant to pyrophosphatase (14).

Although renal osteodystrophy is almost certainly a result of multiple factors, a number of which are known, the present study suggests that $\mathrm{P}_{2} \mathrm{O}_{7}$ may also be involved in the pathogenesis of this condition. The increased bone $\mathrm{P}_{2} \mathrm{O}_{7}$, which is resistant to pyrophosphatase, could have major implications in disturbing normal bone calcification processes. Termine and Posner (15) have suggested that $\mathrm{P}_{2} \mathrm{O}_{7}$ existing in the transphosphorylated form could prevent the conversion of amorphous calcium-phosphate to crystalline apatite. Russell and Avioli (16) have shown that the amount of amorphous calcium-phosphate is increased in the bones of uremic animals. In the present study, percent bone ash was found to be significantly reduced in uremic bones with high $\mathrm{P}_{2} \mathrm{O}_{7}$ content. In addition there was a significant inverse correlation in the high $\mathrm{P}_{2} \mathrm{O}_{7}$ bones between duration of dialysis and percent bone ash.

However, what may be more important than $\mathrm{P}_{2} \mathrm{O}_{7}$ disturbing bone calcification mechanisms is the relationship found between bone $\mathrm{P}_{2} \mathrm{O}_{7}$ content and soft tissue calcification. All dialyzed uremic patients who had a bone $\mathrm{P}_{2} \mathrm{O}_{7}$ level greater than $1.4 \mathrm{mg} / \mathrm{g}$ had extensive pulmonary calcification. In addition no uremic patient with normal bone $\mathrm{P}_{2} \mathrm{O}_{7}$ had more than a slight elevation of the pulmonary calcium content. The pulmonary calcium-phosphate deposits in patients with high bone $\mathrm{P}_{2} \mathrm{O}_{7}$ were also high in $\mathrm{P}_{2} \mathrm{O}_{7}$. Low $\mathrm{P}_{2} \mathrm{O}_{7}$ pulmonary calcification was found in 
one nondialyzed uremic patient who had normal bone $\mathrm{P}_{2} \mathrm{O}_{7}$. The thermochemical properties of this deposit were unlike those found in uremic patients but similar to those described in hypercalcemic patients (3). This would suggest that either this deposit did not occur as a result of the uremic state or else visceral calcification in nondialyzed uremic patients is different from that found in dialyzed uremic patients.

The present study gives little insight into the mechanism responsible for the disturbed $\mathrm{P}_{2} \mathrm{O}_{7}$ metabolism in dialyzed uremic patients. The fact that $\mathrm{P}_{2} \mathrm{O}_{7}$ may exist in bone in the transphosphorylated form would suggest that nucleotide metabolism might be abnormal in uremic patients. However, since magnesium was found to be significantly higher in uremic patients' bones containing high $\mathrm{P}_{2} \mathrm{O}_{7}$ levels and high magnesium levels have uniformly been found in visceral calcium-phosphate deposits containing $\mathrm{P}_{2} \mathrm{O}_{7}$ (3) a disturbance of magnesium metabolism might be responsible for the excess $\mathrm{P}_{2} \mathrm{O}_{7}$ deposition. It is possible that hypermagnesemia alone could cause the deposition of magnesium $\mathrm{P}_{2} \mathrm{O}_{7}$ in soft tissue and bones. Since magnesium is tightly bound to ATP, it is conceivable that a magnesium ATP salt undergoes a phosphoryl transfer reaction and that both magnesium and $\mathrm{P}_{2} \mathrm{O}_{7}$ are released and subsequently bound to the bone crystal. Thus, disturbances in magnesium and ATP metabolism resulting in increased bone $\mathrm{P}_{2} \mathrm{O}_{7}$ are not mutually exclusive. This explanation would imply an abnormal release of magnesium ATP from cells into the circulation.

\section{ACKNOWLEDGMENTS}

We thank Dottie Goodman and K. Robbins for secretarial assistance.

This work was supported by General Veterans Administration Research funding, Easter Seal Research Foundation Grant R-7223, Shriners Hospital, Chicago; National Institutes of Health Clinical Research Center Grant RR-69, and National Science Foundation-Research Applied to National Needs GI-44255.

\section{REFERENCES}

1. Fleisch, H., and S. Bisaz. 1962. Mechanism of calcification: Inhibitory role of pyrophosphate. Nature (Lond.). 195: 911 .
2. Yendt, E. R., T. B. Connor, and J. E. Howard. 1955. In vitro calcification of rachitic rat cartilage in normal and pathological human sera with some observations on the pathogenesis of renal rickets. Bull. Johns Hopkins Hosp. 96: 1-19.

3. Alfrey, A. C., and C. C. Solomons. 1976. Extraosseous calcification. Evidence for abnormal pyrophosphate metabolism in uremia. J. Clin. Invest. 57: 000-000.

4. Russell, R. G. G., S. Bisaz, and H. Fleisch. 1969. Pyrophosphate and diphosphonates in calcium metabolism and their possible role in renal failure. Arch. Intern. Med. 124 : 571-577.

5. David, S. D., S. Sakai, J. Granda, J. S. Cheigh, R. R. Riggio, K. H. Stenzel, and A. L. Rubin. 1973. Role of pyrophosphate in renal osteodystrophy. Trans. Am. Soc. Artif. Intern. Organs. 19: 440-445.

6. Alfrey, A. C., and N. L. Miller. 1973. Bone magnesium pools in uremia. J. Clin. Invest. 52: 3019-3027.

7. Perkins, H. R., and P. G. Walker. 1958. The occurrence of pyrophosphate in bone. J. Bone Jt. Surg. Am. Vol. 40B : 333-339.

8. Cartier, P. 1959. La minéralisation du cartilage ossifiable. VIII. Les pyrophosphates du tissu osseux. Bull. Soc. Chim. Biol. 41 : 573-583.

9. Bisaz, S., R. G. G. Russell, and H. Fleisch. 1968. Isolation of inorganic pyrophosphate from bovine and human teeth. Arch. Oral Biol. 13: 683-696.

10. Burton, F. G., M. W. Neuman, and W. F. Neuman. 1969. Possible role of crystals in the origins of life. I. The adsorption of nucleosides, nucleotides and pyrophosphate by apatite crystals. Curr. Mod. Biol. 3: 20-26.

11. Krane, S. M., and M. J. Glimcher. 1962. Transphosphorylation from nucleoside $\mathrm{di}$ - and triphosphates by apatite crystals. J. Biol. Chem. 237: 2991-2998.

12. Jung, A., S. Bisaz, and H. Fleisch. 1973. The binding of pyrophosphate and two diphosphonates by hydroxyapatite crystals. Calcif. Tissue Res. 11: 269-280.

13. Taves, D. R., and R. C. Reedy. 1969. A structural basis for the transphosphorylation of nucleotides with hydroxyapatite. Calcif. Tissue Res. 3: 284-292.

14. Cathala, G., et C. Brunel. 1973. L'Activité pyrophosphatasique de la phosphatase alcaline du cerveau. Biochim. Biophys. Acta. 315: 73-82.

15. Termine, J. D., and A. S. Posner. 1967. Amorphous/ crystalline interrelationships in bone mineral. Calcif. Tissue Res. 1: 8-23.

16. Russell, J. E., and L. V. Avioli. 1972. Effect of experimental chronic renal insufficiency on bone mineral and collagen maturation. J. Clin. Invest. 51 : 3072-3079. 